\title{
Nutritional, Functional and Microbiological Analysis of Powdered Seed of Moringa oleifera
}

\author{
Abiye A. Ibiene, Nelly C. Ekwuribe, Anwuli U. Osadebe*, Phillip O. Okerentugba \\ Department of Microbiology, University of Port Harcourt, P.M.B. 5323, Choba, Nigeria
}

Received April 10, 2021; Revised May 11, 2021; Accepted June 25, 2021

\section{Cite This Paper in the following Citation Styles}

(a): [1] Abiye A. Ibiene, Nelly C. Ekwuribe, Anwuli U. Osadebe, Phillip O. Okerentugba, "Nutritional, Functional and Microbiological Analysis of Powdered Seed of Moringa oleifera," International Journal of Biochemistry and Biophysics, Vol. 9, No. 1, pp. 1 - 7, 2021. DOI: 10.13189/ijbb.2021.090101.

(b): Abiye A. Ibiene, Nelly C. Ekwuribe, Anwuli U. Osadebe, Phillip O. Okerentugba (2021). Nutritional, Functional and Microbiological Analysis of Powdered Seed of Moringa oleifera. International Journal of Biochemistry and Biophysics, 9(1), 1 - 7. DOI: 10.13189/ijbb.2021.090101.

Copyright $\mathrm{C} 2021$ by authors, all rights reserved. Authors agree that this article remains permanently open access under the terms of the Creative Commons Attribution License 4.0 International License

\begin{abstract}
This study looked to establish the proximate composition, mineral content, water absorption capacity, energy values and microbial load of the seeds of Moringa oleifera following processing. The study was carried out using standard physicochemical and microbiological techniques. Proximate analysis revealed that $M$. oleifera seed powder was rich in protein $(34.39 \%)$ and fat $(37.76 \%)$. The mean crude fibre, ash and carbohydrate values were $5.10 \%, 5.93 \%$ and $9.42 \%$ respectively while moisture was relatively low at $7.40 \%$. The water absorption capacity, gross energy and metabolisable energy levels were determined as 428.01\%, 509.67 Kcal/100g and 398.22 $\mathrm{Kcal} / 100 \mathrm{~g}$ respectively. The heavy metal levels were low to negligible but the calcium and phosphorus levels were somewhat high at $437.85 \mathrm{mg} / \mathrm{kg}$ and $525.10 \mathrm{mg} / \mathrm{kg}$ respectively with a ratio of 0.834 . Counts of $1730 \mathrm{CFU} / \mathrm{g}$ and $121 \mathrm{CFU} / \mathrm{g}$ were obtained for total heterotrophic bacteria and total fungi. The fungi and bacteria obtained were Rhizopus stolonifer, Aspergillus niger, Bacillus, Staphylococcus aureus, Pseudomonas aeruginosa, Proteus and Micrococcus luteus. No coliforms were recorded. The results from this study established $M$. oleifera seed powder as a good source of energy, protein, fat, calcium and phosphorus amongst other minerals and nutrients. Its nutritional and mineral content support coagulation/ flocculation and use in livestock and aquaculture feed.
\end{abstract}

Keywords Proximate Composition, Mineral Content, Energy, Functional Properties Moringa oleifera, Nutrition, Bacteria, Fungi

\section{Introduction}

Moringa oleifera is known by several common names including the drumstick tree, the horseradish tree, the benzolive tree or the kelor tree. It is the most extensively studied member of the genus Moringa, part of the family Moringaceae. The genus, Moringa, consists of 13 other known species. The plant is native to the tropics and has been recorded across countries of Africa, Asia and South America. It is a perennial fast-growing plant that could occur as a shrub or as a tree normally measuring 2.5 to $15 \mathrm{~m}$ in height. It flowers and fruits biannually and is readily propagated via its seeds or cuttings. $M$. oleifera produces white fragrant flowers and its fruits can get up to $45 \mathrm{~cm}$ in length. Its tap root systems make it drought-resistant; it, thus, thrives in semi-arid regions with sandy to loamy soils. The species has shown a preference for soils with a $\mathrm{pH}$ level of around 9 [1,2].

$M$. oleifera has been described as a miracle plant owing to its numerous applications. It is a versatile crop that has nutritional, medicinal and environmental relevance especially in developing countries. It is not only consumed as a vegetable in a number of developing countries, but serves as an important source of vegetable oil too. This oil referred to as ben oil is typically extracted from the seed. Each seed is known to yield in excess of $30-40 \%$ by weight of the oil. Ben oil is resistant to rancidity, non-sticky and non-drying. It is multi-purpose and can be consumed with salads and other meals or employed in industry for machine lubrication, and 
manufacture of perfumes and hair care products [3]. Its leaves, flowers, fruits, and roots are often added to local dishes or eaten on their own. The seed residue left after oil extraction has been employed as an animal feed in certain regions. Its leaves are also useful in this regard. Its therapeutic properties are well known. Anwar et al. [4] maintain that the seeds, leaves, bark and roots have been used for the treatment of rheumatism, venomous bites, scurvy, cold sores and for enhancing cardiac function. Additionally, the leaf extracts improve thyroid gland function and regulate cholesterol levels. It is recommended for the treatment of anaemia in expectant mothers $[3,5]$.

The reuse or recycling of "waste" is a fundamental part of waste management as it not only reduces that volume of waste requiring disposal but eliminates the need to manufacture products to carry out the function to which the recycled material has been applied thereby eliminating further waste generation and cutting costs. Different parts of the M. oleifera plant are often redirected to alternative uses. The plant has been applied in farming for several purposes including biomass generation during alley cropping, manure (seed cake and leaves) for soil improvement and as a bio-pesticide that prevents the damping off of seedlings. The leaves are particularly versatile. Apart from direct consumption of the leaves by humans and animals, the juice produced from the crushed leaves is a popular follicular nutrient as well. The leaves may be crushed and used as a domestic cleaning agent due to its phytochemical content. The crushed leaves are further used in the production of biodiesel and for manure. The powdered seeds are useful in the reduction of turbidity in honey and sugarcane juice while the nectar from the flowers may be used as a healthy replacement for honey. It is used for production of commercial products such as gum and blue dye which can be extracted from the tree trunks, and tannin (extracted from the tree bark and from the wood gum) [6-8].

The seed extracts have been studied extensively for their coagulant capabilities and have been applied to water and wastewater treatment with encouraging results. When used in water treatment, the seed extracts have been reported to greatly improve clarity and remove microbial contaminants with only minimal sludge formation unlike that produced when using chemical coagulants. Its role in wastewater treatment as a coagulant has been equated to that of commercial coagulants including those from calcium, aluminium and iron salts $[9,10]$. The observed sorbent and coagulant qualities of the seeds of $M$. oleifera have been linked to the soluble cationic proteins produced as by-products of the oil extraction process [9]. Furthermore, M. oleifera functions effectively as a bio-absorbent for the removal of heavy metals from aqueous media $[11,12]$.

The aim of this study is to establish the proximate composition, mineral content, water absorption capacity, energy values and microbial load of the seeds of Moringa oleifera following processing in order to better appreciate its potential applications.

\section{Materials and Methods}

\section{Sample Collection and Preparation of the Moringa oleifera (MO) Seed Powder}

The MO seeds were obtained in pods from the Michael Okpara University of Agriculture, Umudike, Nigeria where they were also identified and authenticated. The seeds were sorted out manually, dried and then ground using a laboratory blender. The powdered samples were stored in labelled plastic bags and kept at room temperature in the dark until required.

\section{Determination of Proximate Composition}

The moisture, crude protein, crude fat, total ash, crude fibre and carbohydrate contents of the sample were determined using standard techniques described by the Association of Official Analytical Chemists [13].

\section{Moisture Content}

About $2 \mathrm{~g}$ of the powdered sample was weighed into a crucible of known weight. The sample was then placed in a hot air oven at $105^{\circ} \mathrm{C}$ for $3 \mathrm{~h}$, cooled in a desiccator and weighed again to determine water loss in the powdered sample. Drying was done until a constant weight was achieved.

\section{Ash Content}

For ash content, $10 \mathrm{~g}$ of sample was reduced to ash in a muffle furnace at $550^{\circ} \mathrm{C}$ for 5 hours. After cooling in a desiccator, the ash content was ascertained based on the weight obtained.

\section{Crude Fibre Content}

The crude fibre content was estimated by digesting $2 \mathrm{~g}$ of MO seed powder with sulphuric acid $\left(\mathrm{H}_{2} \mathrm{SO}_{4}\right)$ and sodium hydroxide $(\mathrm{NaOH})$ and then incinerating the residue in a muffle furnace at $550^{\circ} \mathrm{C}$ for $5 \mathrm{~h}$.

\section{Crude Protein Content}

The crude protein content was determined by the Kjeldahl method using $2 \mathrm{~g}$ samples.

\section{Crude Fat Content}

This was established as the ether extract. In order to determine the percentage of fat in the dried sample, $5 \mathrm{~g}$ of MO seed powder sample was exhaustively extracted in a Soxhlet apparatus using petroleum ether (boiling point range $40^{\circ} \mathrm{C}-60^{\circ} \mathrm{C}$ ) as the extractant. The oil weight and 
percentage of oil was calculated.

Carbohydrate Content

The carbohydrate content was determined as nitrogen free extract (NFE) using the formula below:

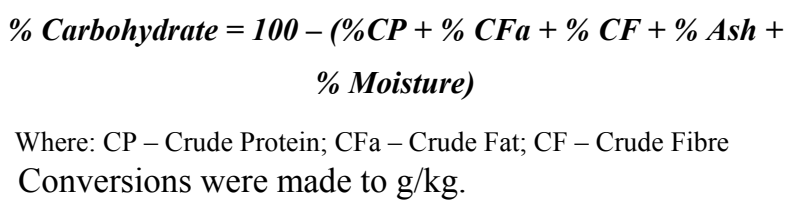

Dry Matter (DM) and Organic Matter (OM) Content

Similar to moisture content, the dry matter content in percentage was determined by drying the samples in an oven at $105^{\circ} \mathrm{C}$ for $3-5 \mathrm{~h}$. The percentage dry matter was calculated as the fraction of the original dry weight multiplied by 100 .

The percentage organic matter content was determined as:

$$
O M=100-(\% A s h)
$$

\section{Analysis of Mineral Composition}

The calcium and phosphorous content of the MO seed powder were determined using the protocol outlined by [14].

The lead, potassium, magnesium, sodium, copper, iron and zinc content in the MO seed powder samples were ascertained using an Atomic Absorption Spectrophotometer (AAS) following nitric acid digestion.

\section{Determination of Functional Characteristics}

Water absorption capacity (WAC)

The water absorption capacity was measured using the modified centrifugation technique as described by [15]. About $2 \mathrm{~g}$ of Moringa oleifera seed powder was mixed with $25 \mathrm{ml}$ distilled water in a $50 \mathrm{ml}$ centrifuge tube with continuous stirring for $1 \mathrm{~min}$. The slurry produced was centrifuged. After the supernatant was decanted, the water retained per gram of sample was determined using the formula below.

\section{WAC $=[$ Weight of bound water $(g) /$ Weight of sample $(g)] x$ $100 \%$}

\section{Metabolisable Energy (ME)}

Metabolisable energy (ME) in $\mathrm{MJ} / \mathrm{kg}$ DM was determined using the equation of Chatepa and Mbewe [16]:

$$
\begin{aligned}
& \operatorname{ME}\left(\mathrm{MJ} \mathrm{Kg}^{-1}\right)=1.549+0.0102 \mathrm{CP}+0.0275 \mathrm{CFa}+0.0148 \\
& \text { Carbohydrate }-0.0034 \mathrm{CF}
\end{aligned}
$$

Where: $\mathrm{CP}$ - Crude Protein $\left(\mathrm{g} \mathrm{kg}^{-1}\right)$; $\mathrm{CFa}$ - Crude Fat $\left(\mathrm{g} \mathrm{kg}^{-1}\right)$; $\mathrm{CF}-$ Crude Fibre $\left(\mathrm{g} \mathrm{kg}^{-1}\right)$

The calculated ME in MJ/kg DM was then converted to Kcal/100g DM.
Gross Energy (GE)

The gross energy (GE) in $\mathrm{kJ} / 100 \mathrm{~g}$ dry matter was estimated as follows;

GE $($ KJ/100g DM) $=17$ CP +37 CFa +16 Carbohydrate

Where: CP - Crude Protein (g/100g); CFa - Crude Fat (g/100g)

The result was converted to Kcal/100g dry matter (DM) by dividing by a factor of 4.184 . The value obtained was further converted to $\mathrm{MJ} / \mathrm{kg}[16,17]$.

\section{Microbiological Analysis of Samples}

Isolation and Enumeration of Total Heterotrophic Bacteria and Total Fungi

For the bacteria, isolation was done on nutrient agar (NA), mannitol salt agar (MSA), cetrimide agar and eosin methylene blue (EMB) agar while plate count agar (PCA) was used for enumeration. For fungi, isolation and enumeration were carried out using potato dextrose agar (PDA) with chloramphenicol added to inhibit bacterial growth. The media were sterilised in an autoclave at $121^{\circ} \mathrm{C}$ and 15 psi for 15 minutes.

A known weight of $10 \mathrm{~g} \mathrm{MO}$ seed powder was added to $90 \mathrm{ml}$ of sterile water, stirred thoroughly and then allowed to stand for about an hour before serial dilution to obtain a six-fold dilution. Following dilution, $1 \mathrm{ml}$ aliquots of the suspension were plated onto the surface of the appropriate medium for the bacteria and fungi using the spread plate technique. Incubation was for $24 \mathrm{~h}$ at $28^{\circ} \mathrm{C}$ for bacteria and $2-4$ days at $30^{\circ} \mathrm{C}$ for fungi. Pure cultures were obtained by streaking onto fresh agar plates. The pure isolates were stored on agar slants until required for further testing.

After incubation, microbial counts on the plates were determined. Only plates with counts of $30-300$ colonies were considered. Counts were expressed as colony forming units (CFU) per gram of powder.

\section{Determination of Total Coliform Count}

The multiple tube fermentation technique was employed in the enumeration of coliform bacteria [18]. The technique is based on the ability of coliform bacteria to grow and produce gas in lactose-containing liquid medium at $37^{\circ} \mathrm{C}$ after 48 hours. Following incubation, the abundance of coliforms was determined by noting the number of positive and negative tubes and comparing this to a standardised MPN table. Isolation on EMB agar served as the confirmatory test.

\section{Characterisation of Isolates}

The isolated bacteria were characterized based on the morphological, microscopic, and biochemical properties while the fungi were identified by studying under the microscope using lactophenol blue stain. Over 25 standard biochemical tests were employed in the characterisation of the bacterial isolates $[19,20]$. Confirmation was done by comparing to similar species from culture collections that 
had been identified via DNA analysis.

\section{Results and Discussion}

This study highlights the microbiological, functional and nutritional properties of Moringa oleifera seed powder. The powder contained high levels of protein, fat, calcium and phosphorus.

\section{Proximate Composition}

The proximate composition of the MO seed powder samples is illustrated in Figure 1. The dry matter and organic matter content were determined as $92.6 \%$ and $94.07 \%$ respectively. The crude protein and crude fat contents were significant; each being over a quarter of the total nutrient content based on dry matter. Crude protein and crude fat recorded the highest values at $34.39 \%$ and $37.76 \%$ respectively while the moisture content was relatively low.

The results from the proximate analysis tally with other similar studies. Chatepa and Mbewe [16] found values of $28.54 \%, 5.37 \%, 34.91 \%, 7.90 \%$ and $23.27 \%$ for crude protein, ash, crude fat, crude fibre and carbohydrate respectively for the seed of MO in their study of the plant. Sultana [15] studied the leaves of MO and observed somewhat comparable levels of $7.55-8.65 \%$ moisture, $8.05-10.38 \%$ ash, $22.99-29.36 \%$ crude protein, $4.03-$ $9.51 \%$, crude fat, $6.0-9.6 \%$ fibre, $47.25-56.25 \%$ carbohydrate and $81.33-83.73 \%$ organic matter for MO leaves. The metabolisable energy values obtained were in the range of $353.03-368.17 \mathrm{Kcal} / 100 \mathrm{~g}$. A study of MO root powder revealed proximate content values of $57.01 \%$, $18.92 \%, \quad 2.74 \%, \quad 9.31 \%, \quad 4.09 \%$ and $7.95 \%$ for carbohydrate, crude protein, crude fat, crude fibre, moisture and ash respectively [21]. Akin to the current study, other similar studies have reported comparable protein contents of $30.6 \%$ [22], 35.97\% [23], and 39.1\% in MO seed [24]. Hassan et al. [25] and Anhwange et al. [26] reported higher values of $44.14 \%$ and $40.31 \%$ respectively while Ijarotimi et al. [27] and Abiodun et al. [28] had lower protein levels of $18.86 \%$ and $28 \%$ respectively. The high protein content supports the effectiveness of the MO seed powder as a coagulant/ flocculant in water treatment [10].

The low moisture content in the Moringa samples observed in this study is an indication that the activity of the microorganisms would be reduced which increases the shelf life of the MO seed powder. In a study by Manju et al. [29] the moisture content was equally low at $6.43 \%$. The high fat content does not correspond with the values obtained by other researchers who reported lower values of $13.35 \%$ [27]. The crude fat measure in the current study is comparable to the values of $34.91 \%$ obtained by Chapeta and Mbewe [16] but lower than the $13.35 \%$ and $6.0-9.6 \%$ recorded by Ijarotimi et al. [27] and Sultana [15] respectively. These values are still lower than the $38.33 \%$ documented for seeds of Moringa peregrine [30]. The disparities observed between the two species could be accredited to species-based variations and edaphic conditions during cultivation. The crude fat content is a measure of the oil in the seeds. The high crude fat of the Moringa seeds suggests that it is a good source of oil for both domestic and industrial purposes. The high fat content may be considered significant as Moringa is known to comprise more polyunsaturated fatty acids (PUFAs) than saturated fatty acids (SFAs); PUFAs are deemed good fat and are recommended for a wholesome diet. They support healthy living and prevent incidences of certain diseases [15].

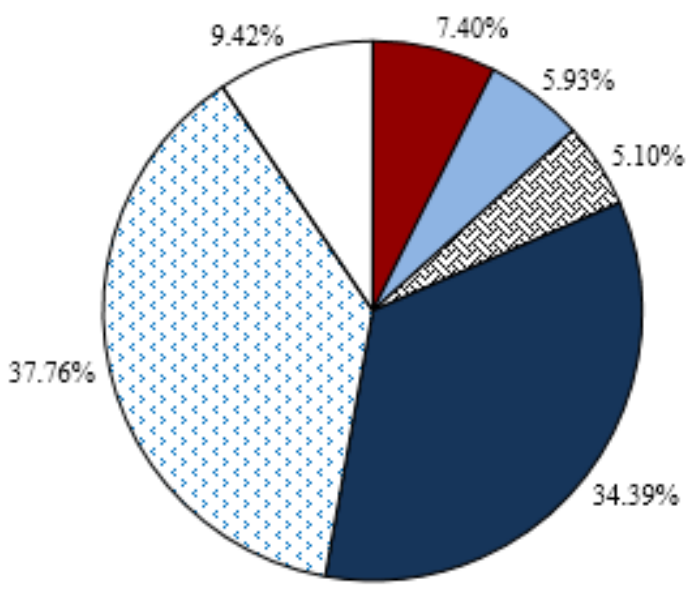

Moisture

$\square$ Ash

هCrude Fibre

- Crude Protein

$\checkmark$ Crude Fat

$\square$ Carbohydrate

Figure 1. Proximate Composition of the Powdered M. oleifera Seeds 
The ash content of $5.93 \%$ observed was comparable to $5.06 \%$ obtained in MO seed in Egypt [31] but greater than the $4.1 \%$ from a similar study in Nigeria [28]. The crude fibre values are akin to values obtained by Ijarotimi et al. [27]. The recorded fibre content, however, is quite low when compared to that of cowpea seeds reported by Mamiro et al. [32]. Dry matter (DM) content is often higher in the MO seed than in the leaves. Chatepa and Mbewe [16] recorded seed DM as $96.86 \%$ but leaves as $93.78 \%$. Similar results are found in other studies that compare that proximate contents from different parts of the MO plant.

\section{Mineral Content}

The mean values of the mineral content in the tested samples are presented in Table 1. Phosphorus, calcium and potassium were the most abundant nutrients in the MO seed powder with values of $525.1 \mathrm{mg} / \mathrm{kg}, 437.85$ $\mathrm{mg} / \mathrm{kg}$ and $74.24 \mathrm{mg} / \mathrm{kg}$ respectively. The heavy metal content of the powder was quite low with only negligible levels of lead. The relatively high Ca:P ratio of 0.834 seen in the MO seed powder samples studied indicates a high nutritional food value particularly with respect to children and the aged. Food with a Ca:P ratio of above or close to 1 is rated as "good" while those with values less than 0.5 are rated as "poor". A $\mathrm{Ca} / \mathrm{P}$ ratio of over 2 facilitates enhanced absorption of calcium in the human body. The $\mathrm{Na}: \mathrm{K}$ and $\mathrm{Ca}: \mathrm{P}$ ratios are considered important measures of the potential body electrolyte balance and bone formation performance of the food. An Na:K ratio of less than 1 is recommended for food for human consumption while a high $\mathrm{Ca}: \mathrm{P}$ ratio is recommended for bone formation and protection [29]. This indicates that that the seed powder is of particular benefit to the elderly and growing children who require calcium and phosphorus for bone and teeth development. With Manju et al. [29] the $\mathrm{Ca} / \mathrm{P}$ ratio was much higher than in the current study at 2.8. The study recorded much higher calcium (357.78 $\mathrm{mg} / 100 \mathrm{~g}$ ) and phosphorus (127.6/100g) levels than the current study with the calcium content surpassing the corresponding phosphorus levels. Optimum $\mathrm{Ca} / \mathrm{P}$ ratio for most livestock is 1.5 while a ratio of 1.33 was found as optimum for catfish aquaculture [33].

Table 1. Mineral Content of Seed Powder of M. oleifera (Mean Values)

\begin{tabular}{cc}
\hline Mineral & Content $\mathbf{( m g} / \mathbf{k g})$ \\
\hline Potassium & 74.24 \\
Calcium & 437.85 \\
Magnesium & 40.50 \\
Sodium & 25.01 \\
Phosphorus & 525.1 \\
Copper & 1.52 \\
Zinc & 1.99 \\
Lead & $<0.002$ \\
Iron & 6.78 \\
C:P ratio & 0.834 \\
Na:K ratio & 0.337 \\
\hline
\end{tabular}

\section{Functional Characteristics}

Table 2 shows the water absorption and energy values for the samples tested. The high water absorption capacity of the MO seed powder has been linked to its high protein content. The WAC value is a key quality of food products especially products employed in the further production of other value-added foods. Lower WAC levels of 158.00 to $415.50 \%$ were recorded for MO leaves in a similar study in Bangladesh [15].

Table 2. Functional and Microbiological Properties of Seed Powder of M. oleifera

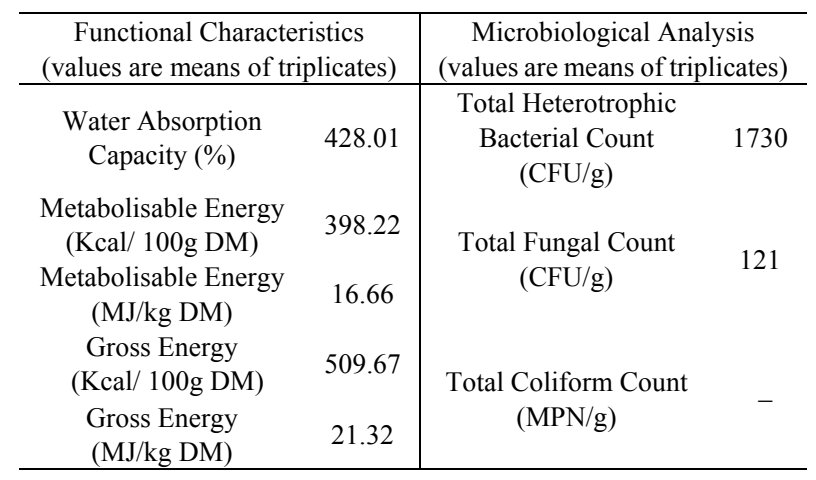

DM - Dry Matter; CFU - Colony Forming Units; MPN - Most Probable Number

The energy levels observed are relative to the fat content of the MO seed powder. The energy values observed in the present study are similar to those reported by Chaepta and Mbewe [16], who found values of 4.1 $\mathrm{Mcal} / \mathrm{kg}(410 \mathrm{Kcal} / 100 \mathrm{~g})$ and $5.1 \mathrm{Mcal} / \mathrm{kg}(510 \mathrm{Kcal} / 100 \mathrm{~g})$ for metabolisable energy and gross energy respectively for MO seed. Metabolisable energy of $3859.92 \mathrm{kcal} / \mathrm{kg}$ (385.99 Kcal/100g) reported by Manju et al. [29] was surprisingly similar to the mean values obtained in the current study in spite of much lower values of other proximate and mineral components when likened to the current study. Although certain researchers maintain that the leaves of MO have higher energy levels than the seed, the values in this study are greater than that found in studies on MO leaf powder [34,35].

\section{Microbiological Analysis}

The fungal and bacterial colonisers of the freshly prepared MO seed powder were Rhizopus stolonifer, Aspergillus niger, Bacillus, Staphylococcus aureus, Pseudomonas aeruginosa, Proteus and Micrococcus luteus. This gives an indication of possible spoilage microorganisms. The Bacillus spp. isolates appeared as pale white circular colonies on nutrient agar plates. The urease producing, motile Proteus spp. appeared characteristically wave-like on blood agar. The Gram positive cocci isolated were $S$. aureus and M. luteus. M. luteus displayed its characteristic yellow colonies on MSA with the coccoid cells appearing in tetrads under the microscope while $S$. aureus showed its characteristic 
golden yellow circular haloed colonies on MSA with cells appearing in clusters and chains under the microscope. The presence of Pseudomonas aeruginosa was seen as blue green colonies on cetrimide agar supplemented with $1 \%$ glycerol. R. stolonifer appeared as white hyphae carrying black conidiophores while $A$. niger was characterised by dark brown biseriate conidial heads. On the PDA plates, they appeared as white later turning black with a felt-like appearance. No coliform bacteria were isolated from the MO seed powder samples. The observed mean total heterotrophic bacterial and total fungal counts are outlined in Table 2. Comparable to the present study, one study found Aspergillus niger and Aspergillus flavus as the only two fungal isolates from MO seed powder [36]. The presence of some of the observed microbial isolates is somewhat unexpected as MO extracts have been shown to have bacteriocidal and fungicidal effects [37-39].

The observed variations in mineral and proximate composition between the current study and other similar studies could be due to variations in edaphoclimatic conditions of the different regions from which the $\mathrm{MO}$ is obtained. The geographical setting, soil structure, available nutrients, cultivation climate and the ripening stage and harvesting time of seeds are all thought to play crucial roles here [3, 40]. The high nutrient content in $M$. oleifera means that it could be an alternative source of protein, fat and minerals in livestock and aquaculture feed formulation and improve livestock production because of the lower cost. The high protein content and water absorption capacity support flocculation/ coagulant activity as well as application in livestock and aquaculture feed.

\section{Conclusions}

The results from this study established $M$. oleifera seed powder as good source of energy, protein, fat, calcium and phosphorus amongst other minerals and nutrients. Its nutritional and mineral content mean that it can be utilised in the composition of livestock and aquaculture feed. The high crude fat of the Moringa seeds suggests that it is a good source of oil for both domestic and industrial purposes while the high protein content and water absorption capacity inform its potential application in water treatment as a coagulant/ flocculant.

\section{REFERENCES}

[1] Muthuraman G., Sasikala S. Turbidity removal from drinking water using natural coagulant. J. Ind. Eng. Chem., 20(4): 1727 - 1731, 2014.

[2] Verma R.K., Kumar R., Sethi M. Use of distinct parts of Moringa oleifera in domestic wastewater treatment (An analogous study). $8^{\text {th }}$ International Conference on Reliability, Infocom Technologies and Optimisation (Trends and future
Directions), Noida, India, 2020, p463 - 467.

[3] Meireles D., Gomes J., Lopes L., Hinzmann M., Machado J. A review of properties, nutritional and pharmaceutical applications of Moringa oleifera: integrative approach on conventional and traditional Asian medicine. Advances in Traditional Medicine, 20:495-515, 2020.

[4] Anwar, F., Latif S., Ashraf M., Gilani A.H. Moringa oleifera: A food plant with multiple medicinal uses, Phytotherapy Research, 21(1):17 - 25, 2007.

[5] Taihiliani P., Kar A. Role of Moringa oleifera leaf extract in the regulation of thyroid hormone status in adult male and female rats. Pharmacology Research, 41:319-323, 2000.

[6] Devkota S., Bhusal K. K. Moringa oleifera: A miracle multipurpose tree for agroforestry and climate change mitigation from the Himalayas - A review. Cogent Food and Agriculture 6: 1805951, 2020.

[7] Mansour A. T., Espinosa C., Garcia-Beltran J. M., Miao L., Francisco D. C. C., Alsaquifi A. S., Esteban M. A. Dietary supplementation of Drumstick tree, Moringa oleifera, improves mucosal immune response in skin and gills of seabream, Sparus aurata, and attenuates the effect of hydrogen peroxide exposure. Fish Physiology and Biochemistry, 46: 981 - 996, 2020.

[8] Olson M. E. Introduction to the Moringa family: Origin, distribution and biodiversity, In: The Miracle Tree: Moringa oleifera, 2019.

[9] Magalhães E.R.B., de Menezes N.N.F., Silva F.L., Garrido J.W.A., Sousa M.A.D.B., dos Santos E.S. Effect of oil extraction on the composition, structure and coagulant effect of Moringa oleifera seeds. Journal of Cleaner Production, 279: 123902, 2021.

[10] Ibiene, A.A., Osadebe, A.U., Ekwuribe, N.C., Okerentugba, P.O. Moringa oleifera Seed Powder for Improvement of the Microbiological and Physicochemical Quality of Sullage and River Water. PSM Biological Research, 6(2): 34-45, 2021 .

[11] Ali E.N. Removal of heavy metals from water and wastewater using Moringa oleifera. In: Murillo-Tovar MA, Saldarriaga-Noreña, H and Saeid A. Trace Metals in the Environment - New Approaches and Recent Advances. London, UK: InTechOpen Publishers, 2020.

[12] Madhuranthakam C.M.R., Thomas A., Akhter Z., Fernandes S. Q., Elkamel A. Removal of chromium (VI) from contaminated water using untreated Moringa leaves as biosorbent. Pollutants 1: $51-64,2021$.

[13] Association of Official Analytical Chemists, AOAC. Official Methods of Analysis. 15th Ed., Washington D.C., USA: AOAC, 2010.

[14] Talapatra S.K., Ray S.C., Sen K.C. The analysis of mineral constituents in biological material. Estimation of phosphorous, chloride, calcium, magnesium, sodium and potassium in feeds stuff. Journal of Veterinary Science, 10:243-246, 1942.

[15] Sultana S. Nutritional and functional properties of Moringa oleifera. Metabolism Open 8: 100061, 2020.

[16] Chatepa L.E.D., Mbewe E.C. Proximate, physical and 
chemical composition of leaves and seeds of Moringa (Moringa oleifera) from Central Malawi: A potential for increasing animal food supply in the 21st century. African Journal of Agricultural Research, 13(51), 2872 - 2880, 2018.

[17] Butcher K., Crown L., Gentry E.J. The International System of Units (SI) - Conversion Factors for General Use. National Institute of Standard and Technology Special Publication 1038:24, 2006.

[18] American Public Health Association, American Water Works Association, APHA and AWWA. Standard methods for the examination of water and wastewater. Washington, DC., USA: American Public Health Association, 2012.

[19] Holt G.T., Krieg R.N., Sneath P.H.A., Staley T.J., Williams T.S. Bergey's Manual of Determinative Bacteriology. $9^{\text {th }}$ Ed. Baltimore, USA: Williams and Wilkins, 1994.

[20] Cheesebrough M. District Laboratory Practice in Tropical Countries. Part II, London, Cambridge University Press, 2006. p58-100.

[21] Nweze N. O., Nwafor F. I. Phytochemical, proximate and mineral composition of leaf extracts of Moringa oleifera Lam. from Nsukka, South-Eastern Nigeria. IOSR J. Pharm Biol. Sci (IOSR-JPBS), 9(1):99 - 103, 2014.

[22] Madubuike P.C., Nwobu D.N., Nwajiobi C.C., Ezemokwe D.E. Proximate analyses of Moringa oleifera seed and characterisation of the seed oil. International Journal of Basic and Applied Sciences, 4(1):71 - 80, 2015.

[23] Olagbemide P.T., Alikwe P.C.N. Proximate Analysis and Chemical Composition of Raw and Defatted Moringa oleifera Kernel. Advances in Life Science and Technology, 24: 92 - 99, 2014.

[24] Moreki J.C., Gabanakgosi, K. Potential Use of Moringa oleifera in Poultry Diets. Global Journal of Animal Scientific Research, 2(2): 109 - 115, 2014.

[25] Hassan K.U., Anjum K., Naseer P.T., Muhammad A., Shahid M., Abdul Waheed S. Influence of Moringa oleifera Decorticated Seed Meal on Broiler Performance and Immunity. Pakistan Veterinary Journal 2017; 37(1):47 - 50, 2017.

[26] Anhwange B.A., Ajibola V.O., Oniye S.J. Chemical studies of the seeds of Moringa oleifera (Lam) and Detarium microcarpum (Guill and Sperr). Journal of Biological Sciences, 4(6):711 - 715, 2004.

[27] Ijarotimi O.S., Adeoti O.A., Ariyo O. Comparative study on nutrient composition, phytochemical, and functional characteristics of raw, germinated, and fermented Moringa oleifera seed flour. Food Science and Nutrition, 1(6): 452463, 2013.

[28] Abiodun O.A., Adegbite J.A., Omolola A.O. Chemical and physicochemical properties of Moringa flours and oil. Global Journal of Science Frontier Research, Biological Sciences 12(5): 8298161, 2012.
[29] Manju C.S., Vaishnava C.S., Khinchi R.K., Meel P., Kumar S., Karnani M. Proximate analysis and chemical composition of Moringa oleifera seeds and its use in broilers diet. International Journal of Chemical Studies, 6(4): 563 - 566, 2018.

[30] Salaheldeen M., Aroua M.K., Mariod A.A., Cheng S.F., Abdelrahman M.A. An evaluation of Moringa peregrina seeds as a source for biofuel. Industrial Crops and Products 61:49-61, 2014.

[31] Barakat H., Ghazal G.A. Physicochemical properties of Moringa oleifera seeds and their edible oil cultivated at different regions in Egypt. Food and Nutrition Sciences, $7: 472-484,2016$.

[32] Mamiro, P. S., Mbwaga, A. M., Mamiro, D. P., Mwanri, A. W., Kinabo, J. L. Nutritional quality and utilization of local and improved cowpea varieties in some regions in Tanzania. African Journal of Food, Agriculture and Nutrition Development, 11: 4490 - 4506, 2011.

[33] Nwanna L.C., Oni O.V. Determination of the calcium and phosphorus ratio for the production of African catfish, Claris gariepinus (Burchell, 1822). Journal of Applied Science and Environmental Management 22(5): 689 - 692, 2018.

[34] Ochi E.B., Elbushra M.E., Fatur M., Ishmail M.A.O., Abdalla H. Effect of Moringa (Moringa oleifera Lam) seeds on the performance and carcass characteristics of broiler chickens. Journal of Natural Sciences Research 5(8):66 - 73, 2015.

[35] Salem H.B., Makkar H.P.S. Defatted Moringa oleifera seed meal as a feed additive for sheep. Animal Feed Science and Technology, 150: 27 - 33, 2009.

[36] Ashidi J.S., Efuntoye O.M., Elebute T. Isolation and Characterisation of Fungal Species Associated with Spoilage of Moringa oleifera Lam. in Storage. Global Research Journal of Microbiology, 2(2) 124 -129, 2012.

[37] Akingbade O.A., Akinjimi A.A., Ezechukwu U.S., Okerentugba P.O., Nwanze J.C., Onoh C.C., Okonko I.O. Antibacterial effect of Moringa oleifera on multidrug resistant Pseudomonas aeruginosa isolates from wound infections in Abeokuta, Ogun State, Nigeria. World Rural Observations 5(3): 6 - 10, 2013.

[38] Ayirezang F.A., Azumah B.K., Achio S. Effects of Moringa oleifera leaves and seeds extracts against food spoilage fungi. Advances in Microbiology, 10(1): 27 - 38, 2020.

[39] Kwami W.S., Saeed H.A., Hamad M.N.M. Screening the antibacterial activity of Moringa oleifera leaves and seeds extract against selected members of bacteria. Saudi Journal of Pathology and Microbiology, 5(8): 370 - 373, 2020.

[40] Ndubuaku U. M., Ndubuaku T.C.N., Ndubuaku N. E. Yield characteristics of Moringa oleifera across different ecologies in Nigeria as an index of its adaptations to climate change. Sustainable Agricultural Research, 3(1): 95 - 100, 2014. 